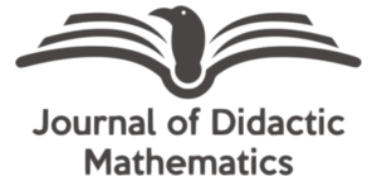

\title{
Using video learning to improve students' mathematical ability
}

\author{
Shiwei Tan* \\ Guangxi Normal University, Guilin, China
}

\section{Lingjie Zou}

Guangxi Normal University, Guilin, China

\author{
Tommy Tanu Wijaya \\ Guangxi Normal University, Guilin, China \\ *Corresponding Author:193776140@qq.com
}

\begin{abstract}
In some traditional large-class classrooms, there are problems such as inactive teaching process and poor teaching pertinence, which makes some students who are easily distracted and have the poor receptive ability cannot keep up with the teaching progress and gradually become students with learning difficulties. This research method using pretest-posttest control group design. The sample of this research is the experimental class method there are 48 students and in the control class 48 students grade 7 junior high school students. based on the results, Micro-classes have the characteristics of short, compact and powerful, which can effectively help students with learning difficulties to learn and master mathematics efficiently within the effective learning time. Based on the characteristics of students with learning difficulties and micro-classes, the author explores the actual improvement effect of micro-classes on the mathematics learning of students with learning difficulties by designing micro-classes in a targeted manner and conducting comparative teaching experiments in the first two parallel classes.
\end{abstract}

Article History:

Received: September 29, 2020

Revised: October 5, 2020

Accepted: October 30, 2020

\section{Keywords:}

Video learning; mathematical ability; algebra

Citation: Tan, S., Zou, L., \& Wijaya, T. T. (2020). Using video learning to improve students' mathematical ability. Journal of Didactic Mathematics, 1(3), 117-126. Doi: 10.34007/jdm.v1i3.364

\section{INTRODUCTION}

Video learning is a new type of mathematics teaching resource (Hermawan, Samsuri, Kurniawati, \& Sofyaningsih, 2018; Wijaya, Ying, \& Suan, 2020). It has short teaching time, smallclustered teaching objectives, small curriculum resources, refined-fine teaching design, refined teaching content, wonderful teaching activities, have a good teaching effect, strong pertinence, dynamic and interesting (Kay \& Kletskin, 2012; Wiriyaudomsatean \& Thinwiangthong, 2019). Can effectively make up for some shortcomings of traditional teaching activities. Through targeted teaching design, dynamic and interesting pictures, highlight key points and solve difficult points, effectively help students with learning difficulties understand basic concepts, mastering problem-solving methods, experience mathematical ideas, and gain a sense of learning achievement within the effective time of student concentration, Improve mathematics learning performance (Huang, Chou, Wu, Shih, Yeh, Lao, Fong, \& Chan, 2020). For most students with learning difficulties, there will be various mistakes in the learning of mathematics. Sometimes it is necessary to repeat the explanation to make the students truly grasp the concept. However, it is more difficult for teachers to repeat the explanation for each student many times. Students can be targeted through micro-classes learning and repeated viewing to enhance students' understanding of knowledge. This study presents the error-prone points of mathematics through micro-classes, and explores the design strategies and actual teaching effects of the micro-classes of mathematics wrong questions, in order to provide a specific reference for teacher teaching 
and student learning.

Mathematics error-prone knowledge points are the basic concept points that learners often make or repeatedly make mistakes when learning and solving mathematical problems (Wijaya, Ying, \& Purnama, 2020; Wijaya, Purnama, \& Tanuwijaya, 2020). That is, for a learner, if all the knowledge points in a certain knowledge system and their nature and the relationship between the knowledge points and the knowledge points can be confident and have good basic mathematics skills, then it can be said that they should learn there is no error-prone point for this knowledge block. If a part of the above is missing, then the learner will have error-prone points for this piece of knowledge, but it may not appear immediately and will be reflected in the subsequent learning process. The learners' error-prone points can not only clearly reflect the learners' deficiencies in basic knowledge, fundamental skills and basic ideas, but also reflect the teacher's problems in cultivating students. Based on the definition of error-prone points, students repeat practice for certain basic mathematical knowledge points or certain math problems, but when they reencounter them, they will still make mistakes again. The knowledge points behind these error-prone math problems are called Mathematics is prone to error.

Wrong questions have two meanings. One is that there are specific errors in the mathematics question itself, which we call the wrong question, and the other is the error that the learner makes in the process of solving the problem. The wrong mathematical question in this article refers to the student's answering difficulties in the process of various types of mathematics. From a cognitive perspective, students' problem-solving errors into four categories: strategic errors, psychological errors, intellectual errors, and logical errors. This classification is relatively comprehensive. It is also widely used. This article mainly focuses on the research of micro-class intervention knowledge errors.

The researcher took the intractable diseases in "factorization with the perfect square formula" as an example to create a lesson design. "factorization with the perfect square formula" is in the third chapter of "factorization" in the second chapter of seventh grade. The key content of the factorization of the "formula method" is the inverse application of the complete square formula, which is generally put together with the teaching of the square difference formula and is the content of one class hour. Here is an example of factorization using the perfect square formula. The converse thinking and overall operation thoughts contained in it are difficult for some students. They involve mathematical ideas such as mathematical abstraction and mathematical reasoning, as well as mathematical methods such as induction and analogy. Cultivate students' symbol awareness, application awareness and model thinking. The focus of teaching is to be able to avoid common mistakes by intervening in error-prone points in advance. While proficient in applying the perfect square formula to factorize, students can clarify the error-prone points of this knowledge point in practical applications. This lesson mainly uses the complete square formula to factorize typical wrong questions as an example to analyze the specific error-prone points contained therein, in order to provide an appropriate reference for the design and application of mathematics wrong questions.

The design of video learning for mathematics wrong questions is based on many theories. This lesson is mainly based on Polya's educational thoughts, combined with variable teaching to create a lesson design (Hidayat \& Sariningsih, 2018; Suan, Ying, \& Wijaya, 2020). Polya has indepth research on the teaching of mathematics problem-solving. He has in-depth thoughts on mathematics problem-solving education. Here, "one idea, two principles, three principles, and four stages" are used to describe his problem-solving ideas briefly.

One idea means Establishing a concept refers to improving learners' ability to solve intractable diseases in mathematics and teaching learners the way of thinking. Following two principles means that mathematics teaching requires understanding mathematics and understanding students. The former determines the level of mathematics that teachers can give to students, while the latter is the basic condition for improving problem-solving teaching.

Grasping the three principles means that mathematics teaching needs to grasp the 
principle of gradual and orderly progress, the principle of active learning and the principle of best motivation, that is, in the process of problem-solving teaching, it is necessary to follow the "intuitive exploration-mathematics clarification-specific application-formation of structure". At the same time, teachers need to actively guide learners, let learners actively explore and discover problem-solving laws, stimulate learners' desire for knowledge, and enable students to solve problems in the best state.

Grasping the four significant stages refers to clarifying the problem-drawing up a planrealizing the plan-reviewing and testing. To clarify the problem is the work of reviewing and analyzing the problem before solving the problem. The drawing up of the plan is to find the known and the unknown. The realization plan is to judge the correctness and logic of each step of the solution through a series of self-reflection questions. Retrospective testing refers to reviewing the problem-solving ideas and checking the correctness of the problem-solving ideas. At the same time, you can try to explore another one or more ways to answer this question.

Variant teaching refers to an education and teaching mode that transforms exercises or concepts so that learners can re-recognize under different learning backgrounds, different thinking angles, and different problem content (Dewi, Wijaya, Budianti, \& Rohaeti, 2018; Yi, Ying, \& Wijaya, 2019). Variation teaching is divided into five categories: changing the question type, the essence remains the same (Hidayat \& Sariningsih, 2018); changing the condition, the conclusion remains the same; the condition does not change, the conclusion is changed; the topic remains the same, and the solution method (Aminah, Wijaya, \& Yuspriyati, 2018). In solving the various "difficult and miscellaneous diseases" encountered by junior high school students in learning mathematics (Yang, Tseng, \& Wang, 2017), variant teaching is a more effective teaching method (Tan, Zou, Wijaya, Suci, \& Dewi, 2020; Wijaya et al., 2020). Appropriate use of variant teaching can create a more lively teaching atmosphere and develop students' mathematics vision (Wijaya, Ying, \& Purnama, 2020a), stimulate students' mathematical thinking and cultivate students' innovative spirit. However, in variant teaching, it is always necessary to master the degree of "variation", that is, to avoid "variation" purely for the sake of "variation". It is necessary to take learners as the main body to enhance learners" participation. The degree of difficulty needs to have a gradient, and the number of variant questions needs to be moderate.

Below, the author chooses two classes in the 7th grade, junior high school to carry out teaching experiments using video learning to study the mathematics wrong-question microclasses to improve the mathematics learning effect of students with learning difficulties.

\section{METHOD}

This research method using pretest-posttest control group design in a middle school in Guilin City, two parallel classes for the 7th grade, junior high school were selected, one of which was used as an experimental class using video learning and the other was used as a control class. The basic situation is as follows:

Experimental class: There are 48 students in the general class of the first grade, with good mathematics foundation, most of the students have medium grades, but they have a strong desire to learn and can complete their homework on time. The average grade of mathematics at the end of the first semester of junior high is 68.02;

Control class: There are 48 students in the general class of the first grade, with good mathematics foundation, most of the students have medium grades, but they have a strong desire to learn and can complete their homework on time. The average score of the first semester of junior high school is 68.26.

The pre-experiment test consists of two parts: actual classroom learning behaviour record and mathematical cognition test. The actual classroom behaviour record is mainly in the normal classroom, the students in the two classes are in a natural state, the students' learning conditions are recorded, and the learning behaviours are analyzed to compare whether the learning 
conditions of the two classes are the same; mathematical cognitive test The content is mainly about the students' actual mastery of the common factor method and the square difference formula in the formula method. This experiment mainly compares the students' mathematical cognition level through the test questions.

\section{RESULTS AND DISCUSSION}

The actual classroom behaviour chooses the actual classroom performance of the firstsemester chapter 3 factorization formula method using the square difference formula to factorize this class, the students in the classroom are in a natural state, observe the overall mathematics classroom student situation, and analyze their classroom behaviour. The statistical results are shown in Table 1.

Table 1. Lesson plan between experimental class and controlled class

\begin{tabular}{|c|c|c|}
\hline & Experimental class & Controlled class \\
\hline Before class & $\begin{array}{l}\text { Prepare textbooks before class and look } \\
\text { relaxed. } \\
\text { Students with learning difficulties: read } \\
\text { quietly and pay attention to what the } \\
\text { teacher is doing from time to time. } \\
\text { Students with learning difficulties: } \\
\text { looking for books and pens, unable to } \\
\text { participate in the teaching process in } \\
\text { time; chatting with classmates }\end{array}$ & $\begin{array}{l}\text { Prepare textbooks before class and look } \\
\text { relaxed. } \\
\text { Middle school students: read quietly and } \\
\text { draw lines. } \\
\text { Students with learning difficulties: looking } \\
\text { for books and pens, unable to participate in } \\
\text { the teaching process in time; chatting with } \\
\text { classmates }\end{array}$ \\
\hline In class & $\begin{array}{l}\text { Middle school students: focus on video } \\
\text { learning, sometimes recording the key } \\
\text { points; students with learning difficulties: } \\
\text { able to concentrate on listening to the } \\
\text { teacher's explanation in the first } 10 \\
\text { minutes, and then start doing small } \\
\text { movements and reading textbooks }\end{array}$ & $\begin{array}{l}\text { Middle school students: Focus on seeing, } \\
\text { answer keywords, read the teacher's } \\
\text { blackboard. } \\
\text { Students with learning difficulties: Be able } \\
\text { to concentrate on listening to the teacher's } \\
\text { explanation in the first } 10 \text { minutes, and } \\
\text { then start doing small movements and } \\
\text { reading another textbooks }\end{array}$ \\
\hline
\end{tabular}

Excellent students, middle school Excellent students, middle school students: students: able to hand in homework on able to hand in homework on time

After class time Students with learning difficulties: unable Students with learning difficulties: unable to hand in homework on time to hand in homework on time

By observing the actual classroom performance of the students in the two classes, the students in the experimental class and the controlled class have a more active learning attitude, and at the same time can actively participate in teaching activities, and complete the exercises on time and independently after class. The academic situation of the two classes basically the same. After being given treatment, students with learning difficulties can be the same as the control class. video learning helps students with learning difficulties, to continue to concentrate on the material provided by the teacher. therefore, the abilities of students with learning difficulties can develop and be the same as other students.

The content of the mathematical cognition test is the common factor method and the formula method-the square difference formula in the factorization. All students in the experimental class and the control class can basically do it and complete the test carefully. The pre-test data of the experimental class and the control class were ranked according to their scores, and then divided into 4 evenly. The average of each group was calculated and the independent sample t-test was performed. The results are shown in Table 2. 
Table 2. Learning cognitive test of students in experimental class and control class

\begin{tabular}{ccccc}
\hline & $0-25 \%$ & $25 \%-50 \%$ & $50 \%-75 \%$ & $75 \%-100 \%$ \\
\hline Experimental class Average score & 82.667 & 76.667 & 69.500 & 57.333 \\
Controlled class average score & 80.667 & 75.167 & 66.167 & 54.333 \\
$\mathrm{p}$ value & 0.193 & 0.077 & 0.054 & 0.383 \\
\hline
\end{tabular}

By observing the above table, there is no significant difference between the experimental class and the control class in the top 25\%, 25\%-50\%, 50\%-75\% and 75\%-100\% of the students $(\mathrm{p}=0.193>0.05, \mathrm{p}=0.077>0.05, \mathrm{p}=0.054>0.05, \mathrm{p}=0.383>0.05)$ The level of mathematical cognition is basically the same.

The total time implementation using video learning in the experimental class is 15 minutes. The topic is the basic concept of applying the complete square formula for factorization and the practical application of the two-in-one mathematics class stack micro-class. After the two microclasses are played, the posttest test paper will be issued immediately, and the test paper will be recovered after 20 minutes.

In the control class, time for the teacher to explain the concept is 15 minutes, and the subject is a traditional classroom video lesson that uses the complete square formula to factorize. After the micro lesson is played, the posttest test paper will be issued immediately, and the test paper will be recovered after 20 minutes.

The similarities and differences between traditional classroom video lessons and mathematics lessons are as follows: Traditional classroom uses the classic analogy of old knowledge and introduce new knowledge; judge examples and clarify methods; list the question types and explain them in turn; class summary and guide memories. These four links fully explain the application of the complete square formula to factor break down. However, the teaching time is long and the teaching process is monotonous, without highlighting the important and difficult points.

The mathematics class stack micro-class adopts a two-in-one model of basic knowledge and practical application. First, the basic knowledge micro-class, the duration is 6 minutes, the theme is the understanding of factorization using the perfect square formula, and the content is divided into five links: review-analogy thinking-induction and generalization-sledgehammer testsummary Rethinking, guiding students to explore new knowledge, progressively. Second, the practical application of the micro-class, its duration is 7 minutes, the topic is the application of factorization using the perfect square formula, and the content is divided into six sections: review-typical questions-try to answer-solution analysis-variant training-summary reflection, guide students to acquire the law from the variant, master the model, learn by changing, and change while learning.

The two-in-one mode micro-classes of the experimental class, one of which is to understand the micro-classes, aims to build a knowledge system of factorization based on the students' understanding of the completely flat method, and at the same time penetrate the mathematical ideas of analogy and induction. For example, in the review section, by reviewing the factorization methods (one is the common factor method, the second is the formula method, the formula method includes the square difference formula) and then guide students to analogize the square difference formula Thinking about whether the complete square formula is used from right to left is factorization, it implies that if the complete square formula can decompose the factors, then it and the square difference formula are both formula methods in factorization. It not only conveys students' awareness of constructing a knowledge system in stages but also penetrates analogous mathematical ideas

The second is to apply micro-classes to design micro-classes based on the students' basic understanding of factorization using the complete square formula, in which mathematics ideas of infiltration, transformation and reduction, one question is changeable, and one question is multi- 
purpose, help students in the middle school. Change in learning. For example, in the part of variation training, students are guided to transform the complex and tedious variation questions into simple known ones through algebraic operations such as adding minus signs, removing parentheses, and seeing them as a whole, and then applying mathematical models Solve, transform complexity into simplicity, difficulty into easy, unfamiliar into familiarity. Use the ideas of transformation and return to guide students to think about problem-solving methods, exercise problem-solving thinking, accumulate problem-solving experience, improve problem-solving ability, and enhance problem-solving confidence as shown in Figure 1.

Fifth.Variant training

\section{Factor the following polynomials}

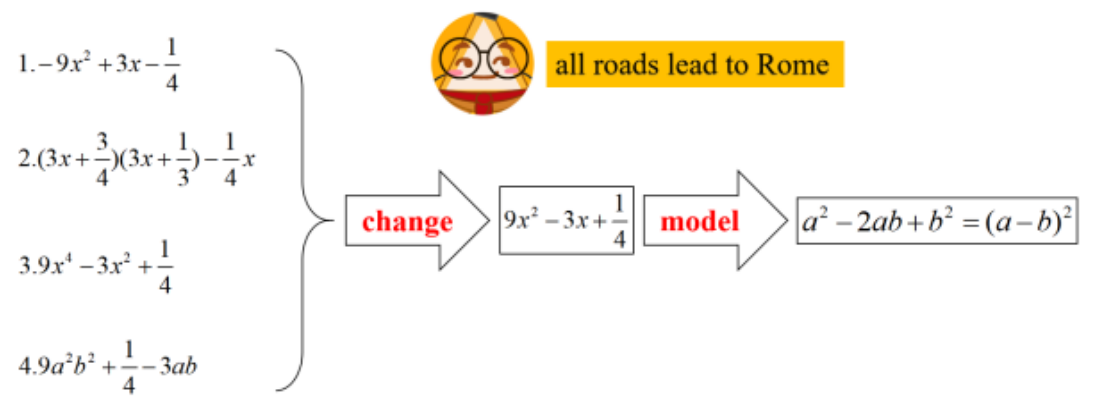

Figure 1. Model summary with video learning

Starting from the reverse direction of the complete squared difference formula model, it conveys students' $1 \rightarrow 4$ questions of changeable thinking, allowing students to jump out of the narrow mindset of solving one problem and solving one problem and cultivate students' ability to change one problem and use one problem as shown in Figure 2.

Fifth.Variant training

Factor the following polynomials

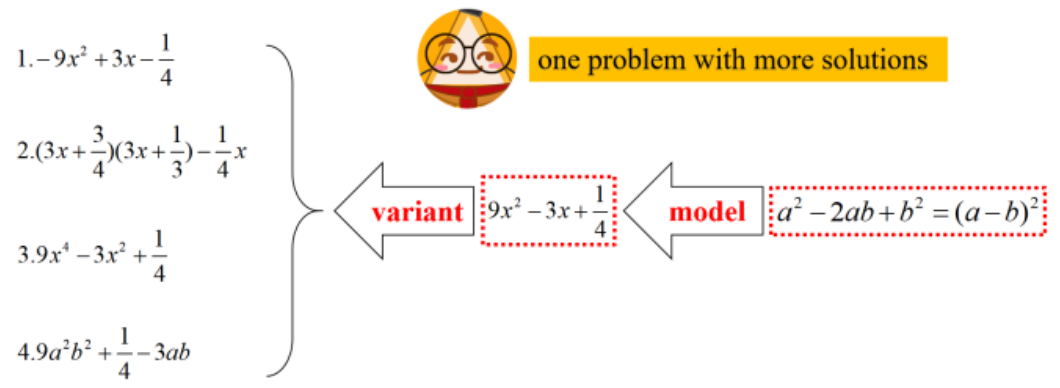

Figure 2. one problem with more various solutions

During the experiment, all students in the experimental class and the control class were able to watch the micro-class seriously and complete the test. After the test is over, sort out the test papers after evaluation and change, and perform independent sample t-test with statistical data combined with the previous test data to get Table 3. It can be seen from the results in the table 3 that in terms of average scores, the experimental class scores are better than those of the control class in the pre-test and posttest. After the independent sample t-test, there is no significant difference $(\mathrm{p}=0.27>0.05, \mathrm{p}=0.22>0.05)$; however, the posttest average scores of the experimental class and the control class have significantly changed, indicating that different types of micro-classes still have a certain impact on students. 
Tabel 3. Pre-test and posttest statistics for experimental and control classes

\begin{tabular}{cccc}
\hline class & $\mathrm{N}$ & pretest $(\mathrm{M} \pm \mathrm{SD})$ & posttest(M $\pm \mathrm{SD})$ \\
\hline Experimental class & 49 & $71.54 \pm 10.18$ & $55.46 \pm 24.55$ \\
Control class & 49 & $69.08 \pm 11.65$ & $49.04 \pm 26.30$ \\
p-value & & 0.27 & 0.22 \\
\hline
\end{tabular}

The four pieces of data were described and box-shaped charts were made for analysis. It was found that the upper quartile, median and lower quartile of the experimental class were higher than the control class, regardless of whether it was pre-test or posttest. Careful observation found that the upper quartile, median, and lower quartile of the experimental class and the control class have undergone significant changes, and the degree of significant change is different, indicating that different types of micro-classes have produced different levels of students. Different degree of influence.

Describe the four pieces of data and make box plots for analysis. The maximum value measured before the experimental class is 88.00 , the upper quartile is 80.00 , the median value is 72.00 , the lower quartile is 64.00 , and the minimum value is. 48.00 , the maximum value measured before the control class is 88.00 , the upper quartile is 76.00 , the median value is 72.00 , the lower quartile is 60.00 , the minimum value is 24.00 , and the maximum value measured after the experimental class is 100.00 , the upper quartile is 75.75 , the median is 53.00 , the lower quartile is 35.00 , the minimum is 15.00 , the maximum value measured after the control shift is 100.00 , the upper quartile is 70.00 , and the median is 49.00 , the lower quartile is 26.25 , and the minimum is 2.00. The analysis found that whether it was pre-test or posttest, the upper quartile, median and lower quartile of the experimental class had higher scores than the control class. After careful study, it is found that the upper quartile, median and lower quartile of the experimental class and the control class have changed significantly, and the degree of significant change is different, indicating that different types of micro-classes have produced different levels of students. The degree of influence is different.

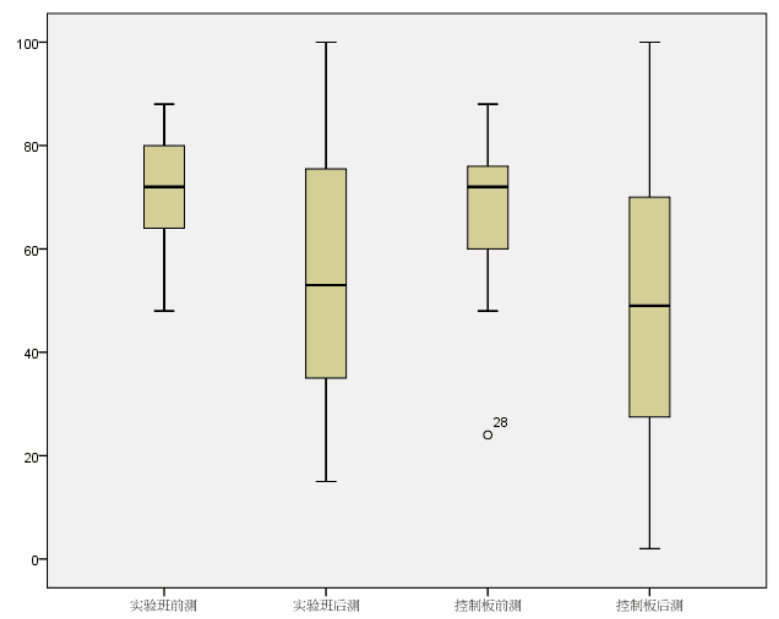

Figure 3. Box diagram analysis of experimental class and control class

Rank the posttest data of the experimental class and the control class according to their scores, and then divide them into 4 evenly. The average of each group is calculated and the independent sample t-test is performed. The p-value results can be seen in Table 4.

In the two different teaching modes, from the post-test scores, there is no significant difference between the top $25 \%, 25 \%-50 \%$ and $50 \%-75 \%$ of the students $(\mathrm{p}=0.101>0.05$, $\mathrm{p}=0.240>0.05, \mathrm{P}=0.102>0.05)$; there is a significant difference between $75 \%-100 \%$ of students $(p=0.001<0.05)$. It shows that the micro-classes of the mathematics class stack have a significant 
effect on improving the mathematics learning of students with learning difficulties. Perform an independent sample t-test for each item in the posttest can be seen in Table 5.

Tabel 4. Posttest score distribution

\begin{tabular}{ccccc} 
& $0-25 \%$ & $25 \%-50 \%$ & $50 \%-75 \%$ & $75 \%-100 \%$ \\
\hline Average of experimental class & 88.167 & 63.750 & 44.167 & 25.750 \\
Average of control class & 82.000 & 60.250 & 39.417 & 14.500 \\
p-value & 0.101 & 0.240 & 0.102 & 0.001
\end{tabular}

Tabel 5. Analysis of test questions after experimental class and control class

\begin{tabular}{cc}
\hline posttest & p-value \\
Questions one & 0.725 \\
Questions two & 0.599 \\
Questions three & 0.006 \\
\hline
\end{tabular}

In the posttest, the problem with significant differences between the two classes is the third question $(\mathrm{p}=0.006<0.05)$. The average score of the experimental class is 55.46 , and the average score of the control class is 49.04 , which shows that the completion of this question is better than that of the control class. The question can be seen in figure 4.

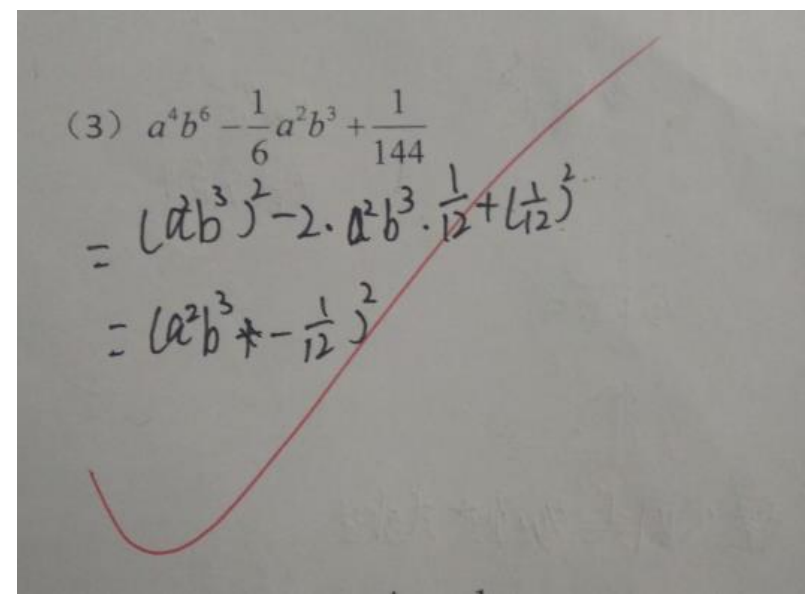

(a)

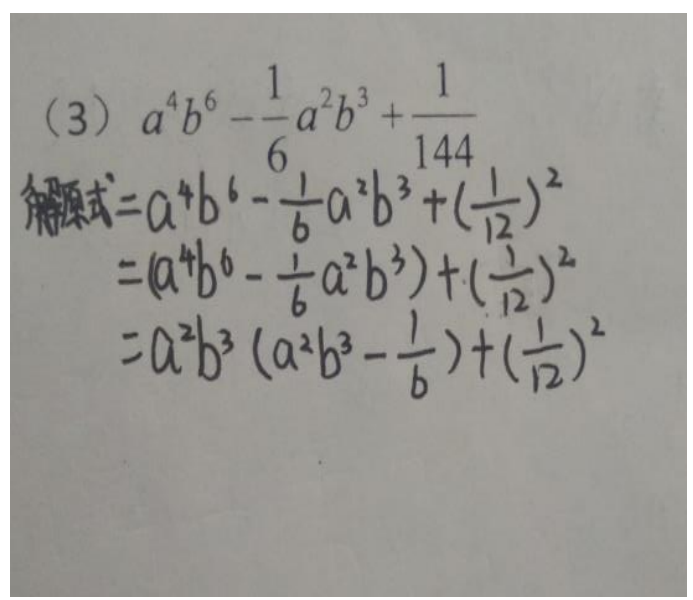

(b)

Figure 4. (a). students' answers in the experiment class (b). students' answers in the Controlled class

Both the mathematics class stack micro-classes played by the experimental class and the traditional classroom video class played by the control class contain methods to explain this type of problem, but the test scores of the control class are far inferior to the experimental class. Analyzing the wrong test papers, it is found that compared with the experimental class, there are more students in the control class who directly simplify the evaluation, indicating that these students do not master new knowledge, do not know, are not proficient, or are not aware of the application of "whole "transformation and conversion" thought to solve the problem. Statistics on the teaching time found that the teacher in the traditional classroom video class took longer to explain the content, but the explanation of the method summary was less.

Based on the above data, it shows that for students with the strongest, stronger and weaker learning ability and acceptance ability, there is no significant difference in the effect of math class stack micro-classes on improving mathematics learning. For students with the weakest learning ability, the "basic knowledge + practical application" two-in-one micro-class in the mathematics class stack allows them to learn knowledge, master methods, and form ideas within an effective time to concentrate their attention. Do your homework better, find a sense of 
achievement in math learning, and be willing to learn, know how to learn, and enjoy learning mathematics. Therefore, for students with short attention spans and weak foundations, the micro-classes with video learning of the mathematics stack can improve mathematics learning better than a traditional classroom.

this research is the same as research that has been done before. Technology in education can increase student interest in learning (Dikovic, 2009; Hernawati \& Jailani, 2019). Technology in education can improve student learning achievements (Wijaya, Jianlan, \& Aditya, 2020; Zhang, Zhou, \& Wijaya, 2020), Technology in education can help students understand mathematical concepts (Cunhua, Ying, Qunzhuang, \& Wijaya, 2019; Roth \& Price, 2016). Suggestion for further research so that they can continue to use video learning to help students with learning difficulties.

\section{CONCLUSION}

The results of this study indicate that video learning can help students with learning difficulties to be able to follow mathematics material well. So it can be seen that the learning outcomes of students with learning difficulties are the same as other smart students. Through the overall analysis of this experiment, the mathematics class stack is vivid, interesting, structured, and focused. The micro-classes that solve the difficult points can better improve the mathematics learning of the students with learning difficulties. At the same time, this study also has shortcomings. The number of experiments is too few, lacking in generality; the form of watching the micro-class is group viewing, the effect of the experiment is not as good as watching alone, there will be a specific experimental deviation; the test paper before the experiment and the test paper after the experiment need to be further improved.

\section{REFERENCES}

Aminah, S., Wijaya, T. T., \& Yuspriyati, D. (2018). Analisis Kemampuan Komunikasi Matematis Siswa Kelas Viii Pada Materi Himpunan. Jurnal Cendekia: Jurnal Pendidikan Matematika, 2(1), 15-22. https://doi.org/10.31004/cendekia.v2i1.29

Cunhua, L., Ying, Z., Qunzhuang, O., \& Wijaya, T. T. (2019). Mathematics course design based on six questions cognitive theory using hawgent dynamic mathematic. Journal On Education, 02(01), 36-44.

Dewi, S. N., Wijaya, T. T., Budianti, A., \& Rohaeti, E. E. (2018). Pengaruh Model Teams Games Tournament Terhadap Kemampuan Pemahaman Matematik Siswa Kelas XI SMK di Kota Cimahi Pada Materi Fungsi Eksponen. WACANA AKADEMIKA: Majalah Ilmiah Kependidikan, 2(1), 99. https://doi.org/10.30738/wa.v2i1.2570

Dikovic, L. (2009). Implementing dynamic mathematics resources with geogebra at the college level. International Journal of Emerging Technologies in Learning, 4(3), 51-54. https://doi.org/10.3991/ijet.v4i3.784

Hermawan, H., Samsuri, S., Kurniawati, D. P., \& Sofyaningsih, V. (2018). The use of controversial public issues with video and macromedia flash player media in civic education learning. Psychology, Evaluation, and Technology in Educational Research, 1(1), 19-30.

Hernawati, K., \& Jailani. (2019). Mathematics mobile learning with TPACK framework. Journal of Physics: Conference Series, 1321(2). https://doi.org/10.1088/1742-6596/1321/2/022126

Hidayat, W., \& Sariningsih, R. (2018). Kemampuan Pemecahan Masalah Matematis dan Adversity Quotient Siswa SMP Melalui Pembelajaran Open Ended. JNPM (Jurnal Nasional Pendidikan Matematika), 2(1), 109. https://doi.org/10.33603/jnpm.v2i1.1027

Huang, M. C. L., Chou, C. Y., Wu, Y. T., Shih, J. L., Yeh, C. Y. C., Lao, A. C. C., Fong, H., Lin, Y. F., \& Chan, T. W. (2020). Interest-driven video creation for learning mathematics. Journal of Computers in Education, 7. https://doi.org/10.1007/s40692-020-00161-w

Kay, R., \& Kletskin, I. (2012). Evaluating the use of problem-based video podcasts to teach mathematics in higher education. Computers and Education, 59(2), 619-627. 
https://doi.org/10.1016/j.compedu.2012.03.007

Roth, M. A., \& Price, J. K. (2016). ICT in Education in Global Context. In Lecture Notes in Educational Technology. https://doi.org/10.1007/978-3-662-47956-8

Suan, L., Ying, Z., \& Wijaya, T. T. (2020). Using hawgent dynamic mathematics software in teaching arithmetic operation. International Journal of Education and Learning, 2(1), 25-31. https://doi.org/10.31763/ijele.v2i1.97

Tan, S., Zou, L., Wijaya, T. T., Suci, N., \& Dewi, S. (2020). Improving student creative thinking ability with problem based learning approach using hawgent. Journal on Education, 2(4), 303312.

Wijaya, T. T., Jianlan, T., \& Aditya, P. (2020). Developing an Interactive Mathematical Learning Media Based on the TPACK Framework Using the Hawgent Dynamic Mathematics Software. Emerging Technologies in Computing, 318-328. https://doi.org/10.1007/978-3-03060036-5

Wijaya, T. T., Purnama, A., \& Tanuwijaya, H. (2020). Pengembangan Media Pembelajaran Berdasarkan Konsep Tpack pada Materi Garis dan Sudut Menggunakan Hawgent Dynamic Mathematics Software. JPMI - Jurnal Pembelajaran Matematika Inovatif, 3(3), 205-214. https://doi.org/10.22460/jpmi.v1i3.205-214

Wijaya, T. T., Ying, Z., Chotimah, S., Bernard, M., Zulfah, Z., \& Astuti, A. (2020). Hawgent dynamic mathematic software as mathematics learning media for teaching quadratic functions. Journal of Physics: Conference Series, 1592(1). https://doi.org/10.1088/17426596/1592/1/012079

Wijaya, T. T., Ying, Z., \& Purnama, A. (2020a). The empirical research of hawgent dynamic mathematics technology integrated into teaching. Journal Cendekia: Jurnal Pendidikan Matematika, 04(01), 144-150.

Wijaya, T. T., Ying, Z., \& Purnama, A. (2020b). Using Hawgent dynamic mathematics software in teaching trigonometry. International Journal of Emerging Technologies in Learning, 15(10). https://doi.org/10.3991/ijet.v15i10.13099

Wijaya, T. T., Ying, Z., \& Suan, L. (2020). Gender and Self-regulated Learning During COVID19 Pandemic in Indonesia. Jurnal Basicedu, 4(3), 725-732. https://doi.org/10.31004/basicedu.v4i3.422

Wiriyaudomsatean, T., \& Thinwiangthong, S. (2019). Students' Words in Mathematical Communication in Classroom Using Lesson Study and Open Approach. Journal of Physics: Conference Series, 1340(1). https://doi.org/10.1088/1742-6596/1340/1/012090

Yang, D. C., Tseng, Y. K., \& Wang, T. L. (2017). A comparison of geometry problems in middle-grade mathematics textbooks from Taiwan, Singapore, Finland, and the United States. Eurasia Journal of Mathematics, Science and Technology Education, 13(7), 2841-2857. https://doi.org/10.12973/eurasia.2017.00721a

Yi, L., Ying, Z., \& Wijaya, T. T. (2019). The Trend of Mathematics Teaching Method Has Change From Fragments To Systematics. Journal Cendekia: Jurnal Pendidikan Matematika, 3(2), 471-480. https://doi.org/10.31004/cendekia.v3i2.137

Zhang, X., Zhou, Y., \& Wijaya, T. T. (2020). Hawgent Dynamic Mathematics Software to Teach Line and Angle. JNPM (Jumal Nasional Pendidikan Matematika), 4(2), 237-247. 